CLINICAL STUDY

\title{
Recombinant human GH replacement increases CD34 + cells and improves endothelial function in adults with GH deficiency
}

\author{
Agatha A van der Klaauw ${ }^{1}$, Alberto M Pereira ${ }^{1}$, Ton J Rabelink ${ }^{2}$, Eleonora P M Corssmit ${ }^{1}$, Anton-Jan Zonneveld ${ }^{2}$, \\ Hanno Pijl ${ }^{1}$, Hetty C de Boer ${ }^{2}$, Johannes W A Smit ${ }^{1}$, Johannes A Romijn ${ }^{1}$ and Eelco J P de Koning ${ }^{1,2}$ \\ ${ }^{1}$ Department of Endocrinology and Metabolic Diseases, Leiden University Medical Center, PO Box 9600, 2300 RC Leiden, The Netherlands and \\ ${ }^{2}$ Department of Nephrology, Leiden University Medical Center, Leiden, The Netherlands \\ (Correspondence should be addressed to A A van der Klaauw; Email: a.a.van_der_klaauw@lumc.nl)
}

\begin{abstract}
Objective: Adult patients with GH deficiency (GHD) are at increased risk for cardiovascular morbidity and mortality. Endothelial function, vascular stiffness, and loss of circulating CD34+ cells are considered biomarkers for cardiovascular disease. The aim of this study was to assess vascular structure and function in relation to circulating CD34 + cells in adults with GHD before and during 1 year of recombinant human $\mathrm{GH}(\mathrm{rhGH})$ replacement.

Design: One-year intervention with rhGH.

Patients and methods: Vascular function (flow-mediated dilatation (FMD)) and structure (pulse wave velocity (PWV) and analysis) were assessed in 14 adult patients (nine men) with GHD (mean age 57 years, range 27-71 years). In addition, the number of CD34+ cells was evaluated using flow cytometric analysis. Study parameters were analyzed at baseline, and after 6 months and 1 year of rhGH replacement. Results: rhGH replacement increased IGF-I levels from $10.4 \pm 4.5 \mathrm{mmol} / \mathrm{l}$ at baseline to $18.4 \pm$ $10.1 \mathrm{mmol} / \mathrm{l}$, and $20.5 \pm 8.0 \mathrm{mmol} / \mathrm{l}$, at 6 months, and 1 year respectively $(P=0.001)$. FMD increased from $3.5 \pm 1.8 \%$ to $6.0 \pm 2.5 \%$ and $5.1 \pm 2.5 \%$ during 1 year of rhGH replacement $(P=0.008)$. There was no beneficial effect on PWV, central pulse pressure, central systolic pressure, and augmentation index. The number of CD34 + cells increased from $794.9 \pm 798.8$ to $1270.7 \pm 580.1$ cells $/ \mathrm{ml}$ and to $1356.9 \pm$ 759.0 cells $/ \mathrm{ml}(P=0.010)$.

Conclusion: One year of rhGH replacement in adults with GHD improves endothelial function and increases the number of circulating CD34+ cells.
\end{abstract}

European Journal of Endocrinology 159 105-111

\section{Introduction}

Growth hormone deficiency (GHD) is associated with an increased prevalence of cardiovascular risk factors, such as central obesity, hypertension, dyslipidemia, a decrease in lean body mass, and an increase in insulin resistance $(1,2)$. In addition, abnormalities in vascular function and structure have been described in GHD (3-5). Recombinant human $\mathrm{GH}$ (rhGH) replacement in GHD is aimed at reversing these abnormalities (6-10).

For a decade, bone marrow-derived endothelial progenitor cells have been proposed to play an important role in maintenance and repair of the vasculature. Both re-endothelialization and angiogenic capacity have been put forward as mechanisms by which these cells are involved in vascular repair (11). We, and others, have shown that the number of these cells is reduced in patients with type 1 diabetes (12), with other cardiovascular risk factors, and with established cardiovascular disease $(13,14)$.

There is, however, a continuing debate on the phenotypic characteristics of endothelial progenitor cells $(11,15,16)$. Many groups perform flow cytometric analysis using CD34, CD133, and/or vascular endothelial growth factor receptor (VEGFR) as cell surface markers to characterize the cells. Of these, CD34-positive cells (without VEGFR expression) show a stronger inverse correlation with the presence and the number of cardiovascular risk factors than CD34/VEGFR + cells or cells with other combinations of positive surface markers believed to be endothelial progenitors (17).

Thus, CD $34+$ cells are a bone marrow-derived biomarker for cardiovascular risk, but there is no information on the effects of rhGH replacement on these cells in adults with GHD. Therefore, the aim of our study was to evaluate the effects of rhGH replacement on the number of circulating CD34 + cells and vascular function and structure in adults with GHD.

\section{Methods}

\section{Patients}

Fourteen patients with GHD were included in this prospective open-label intervention study. GHD was 
confirmed in all patients by an insulin tolerance test (nadir blood glucose $<2.2 \mathrm{mmol} /$ ) with a peak $\mathrm{GH}$ concentration $<3 \mu \mathrm{g} / \mathrm{l}$. An additional inclusion criterion was stable hormonal substitution of dysfunctional hormonal axes at least 3 months prior to study start. Exclusion criteria were a hormonally active pituitary tumor, history of cancer, the presence of chronic inflammatory disease, diabetes mellitus, and a history of cardiovascular disease. The study protocol was approved by the medical ethics committee of the Leiden University Medical Center, and written informed consent was obtained from all subjects.

\section{Treatment protocol}

Patients were treated with rhGH for 12 months. After initial measurements were obtained, all patients were treated with s.c. injections of rhGH (Genotropin Pharmacia/Pfizer or Zomacton Ferring, Norditropin NovoNordisk, or Humatrope Lilly), given every evening. The initial dose of $0.2 \mathrm{mg} /$ day $\mathrm{rhGH}$ was individually adjusted each month in the first half year to achieve physiological serum insulin-like growth factor-I (IGF-I) concentrations, within the age-dependent laboratory reference range. The patients were studied at baseline, and 6 and 12 months after GH replacement. During the study, no antihypertensive or lipid-lowering drugs were prescribed.

\section{Study parameters}

Endothelial function Nitric oxide-dependent flowmediated dilatation (FMD), expressed as percentage diameter change in the brachial artery after reactive hyperemia, was measured non-invasively by ultrasonography using standard procedures in our vascular research unit (18). Measurements were performed at the elbow of the right arm using a vessel wall movement system (Wall Track System, Pie Medical, Maastricht, The Netherlands) that consists of an ultrasound imager with a $10 \mathrm{MHz}$ linear array transducer connected to a data acquisition system and a personal computer. Three measurements were averaged to calculate a baseline diameter of the brachial artery. By inflation of a blood pressure cuff for $5 \mathrm{~min}$ at a pressure of $200 \mathrm{mmHg}$, ischemia was applied to the forearm distal to the location of the transducer. Ultrasonography continued for $5 \mathrm{~min}$ after cuff release with measurements at 30-s interval. The widest lumen diameter was taken as a measurement for maximal vasodilatation. Nitroglycerin spray $(400 \mu \mathrm{g})$ was administered to determine endotheliumindependent vasodilatation. All measurements were performed by the same technician with patients supine in a quiet temperature controlled environment after at least $15 \mathrm{~min}$ of rest. All patients were requested to refrain from smoking on the morning of vascular measurements. Control values for FMD were obtained from healthy age-, gender-matched subjects (nine men) with a BMI of $26.6 \pm 2.9 \mathrm{~kg} / \mathrm{m}^{2}$ (age $49.8 \pm 12.4$ years, $P=\mathrm{NS}$ compared with patients). Three control subjects smoked.

Pulse wave velocity (PWV) Arterial stiffness was assessed non-invasively by aortic PWV using standard procedures in our vascular research unit (19). In short, sequential tonometry was performed at the common carotid artery and the femoral artery using a SphygmoCor device (SphygmoCor, Actor Medical, Sydney, Australia) to record the arterial pulse waveform. Pulse transit time between the two sites was determined by the system software from the average of ten consecutive heartbeats. The distance between the two recording sites was measured, and aortic PWV was calculated as the distance traveled by the pulse wave divided by the transit time (in $\mathrm{cm} / \mathrm{s}$ ). The validation of this automatic method and its reproducibility have previously been published (20). The measurements were performed twice in each patient and then averaged to obtain the mean aortic PWV, which was used for statistical analysis. The same control subjects as for the FMD were used.

Central pressure and augmentation index Central pulse pressure was determined by measuring the brachial blood pressure, determining the pulse waveform at the brachial and carotid artery by applanation tonometry using a Millar probe (Millar Instruments, Houston, TX, USA) and applying the calibration method according to Kelly and Fitchett (21) to determine central systolic blood pressure and central pulse pressure (22). This method assumes that the mean arterial pressure and diastolic blood pressure remain constant from the aorta to the large peripheral arteries, which allows central pulse pressure calculation. The same control subjects as for the FMD were used.

CD34-positive cells For enumeration of CD34-positive circulating (CD34 + cells), flow cytometric analysis was performed using a multi-parametric gating strategy based on the International Society of Hematotherapy and Graft Engineering (ISHAGE). This lyse/no-wash method uses Trucount tubes (Becton Dickinson, Franklin Lakes, NJ, USA) that contain a defined number of brightly fluorescent microbeads, permitting the acquisition of absolute counts of cells, even at very low numbers. Circulating CD34+ cells are defined as cells with low expression for CD45, positive for CD34, and located in the lympho gate on a side- and forwardscatter plot. Within $2 \mathrm{~h}$ of blood withdrawal, $50 \mu \mathrm{l}$ EDTA-anticoagulated whole blood was added per Trucount tube (two per subject) by reverse pipetting and directly labeled antibodies were added: CD45-PerCP, CD34-FITC (BD Biosciences, Erembodegem, Belgium). After 30-min incubation on ice and in the dark, the cells were fixed using FACS lysing solution (BD Biosciences), and the samples were measured within $24 \mathrm{~h}$ using a fluorescence-activated cell sorter (FACS) Calibur (BD 
Biosciences). A total of $500000 \mathrm{CD} 45+$ cells were measured (excluding the beads), and the number of CD34+ cells per microliter blood was calculated. Reference values were obtained from nine healthy men with a mean age of $61 \pm 5$ years and a BMI of $24.2 \pm 1.0 \mathrm{~kg} / \mathrm{m}^{2}$ obtained in our center.

Biochemical parameters IGF-I, IGF binding protein-3 (IGFBP-3), fasting levels of glucose, total cholesterol, HDL cholesterol (HDL), and triglycerides (TG) were measured at baseline, after 6 months, and after 1 year of follow-up. LDL cholesterol concentrations (LDL) were calculated using the Friedewald formula. Patients were requested to fast overnight before the blood samples were taken for laboratory measurements of lipid profiles and glucose.

\section{Assays}

Serum IGF-I concentrations $(\mathrm{ng} / \mathrm{ml})$ were measured using an immunometric technique on an Immulite 2500 system (Diagnostic Products Corporation, Los Angeles, CA, USA). The intra-assay variation was 5.0 and $7.5 \%$ at mean plasma levels of 8 and $75 \mathrm{nmol} / \mathrm{l}$ respectively.

IGFBP-3 was measured using an immunometric technique on an IMMULITE Analyzer (Diagnostic Products Corporation). The lower limit of detection was $0.02 \mathrm{mg} / \mathrm{l}$, and inter-assay variation was 4.4 and $4.8 \%$ at 0.91 and $8.83 \mathrm{mg} / \mathrm{l}$ respectively.

A Hitachi P800 autoanalyzer (Roche) was used to quantify serum concentrations of glucose, total cholesterol, and TG. HDL was measured with a homogenous enzymatic assay (Hitachi 911, Roche).

\section{Statistical analysis}

Statistical analysis was performed using SPSS for Windows, version 14.0 (SPSS, Inc., Chicago, IL, USA). Results are scored as the mean \pm s.D., unless specified otherwise. ANOVA-repeated measurements with Sidak correction for multiple comparisons were used. A $P$ value $<0.05$ was assumed to represent a significant difference.

\section{Results}

\section{Patients}

Fourteen patients (nine men) were included in this prospective, open-label intervention study with a mean age of 51 years (range 27-71 years) and a mean BMI of $29.4 \pm 3.9 \mathrm{~kg} / \mathrm{m}^{2}$. GHD was secondary to a nonfunctioning pituitary macroadenoma in 11 patients, to an enlarged pituitary stalk in 2 patients, and idiopathic in 1 patient. Additional clinical characteristics are detailed in Table 1.
Table 1 Clinical characteristics of the included patients.

\begin{tabular}{ll}
\hline & $\mathbf{N}=\mathbf{1 4}$ \\
\hline Age (years, mean (range)) & $50.8(27-71)$ \\
Gender (M/F $(n(\%)))$ & $9(64) / 5(36)$ \\
Etiology of GHD $(n(\%))$ & $11(79)$ \\
$\quad$ Non-functioning pituitary adenoma & $3(21)$ \\
Other & $11(79)$ \\
Treatment of pituitary tumor & $4(29)$ \\
$\quad$ Surgery $(n(\%))$ & $8(57)$ \\
Radiotherapy $(n(\%))$ & $6(43)$ \\
Pituitary deficiencies & $7(50)$ \\
TSH deficiency $(n(\%))^{\text {a }}$ & $1(7)$ \\
ACTH deficiency $(n(\%))^{\text {a }}$ & $4(29)$ \\
LH-FSH deficiency $(n(\%))^{\text {a }}$ & ADH deficiency $(n(\%))$ \\
Smoking $(n(\%))$ & \\
\hline
\end{tabular}

${ }^{a}$ TSH deficiency was treated with thyroid hormone substitution in all TSHdeficient patients. ACTH deficiency was treated with hydrocortisone substitution in all ACTH-deficient patients as was LH-FSH deficiency with either testosterone or estrogen.

\section{Effects of 1 year rhGH replacement}

During rhGH replacement, IGF-I and IGFBP-3 concentrations increased within 6 months after the start of treatment $(P=0.006$ and $P=0.053$ respectively; Table 2), and remained unchanged between 6 months and 1-year rhGH replacement $(P=1.0$ and $P=1.0$ respectively). Total, LDL, and HDL cholesterol remained unchanged as well as fasting glucose and triglycerides during 1 year of rhGH replacement.

\section{Vascular assessment and CD34 + cells during rhGH therapy}

FMD increased during 1 year of rhGH replacement $(P=0.008$; Table 2$)$, most markedly during the first half year of rhGH replacement (Fig. 1 and Table 2). No change in PWV, brachial systolic and pulse pressure, central pulse pressure, central systolic pressure, and augmentation index were observed during GH therapy (Table 2).

The number of circulating CD34+ cells increased from $794.9 \pm 798.8$ to $1270.7 \pm 580.1$ cells $/ \mathrm{ml}$ and, $1356.9 \pm 759.0$ cells $/ \mathrm{ml}$, at 6 and 12 months respectively after treatment ( $P=0.010$; Fig. 2$)$. The reference values of the number of circulating CD34 + cells in nine men with a mean age of $61 \pm 5$ years and a BMI of $24.2 \pm 1.0 \mathrm{~kg} / \mathrm{m}^{2}$ obtained in our center was $1913.6 \pm 1640.2 \mathrm{cells} / \mathrm{ml}$. The number of erythrocytes, lymphocytes, and leukocytes (CD45-positive cells) remained unchanged.

There were no correlations between the change in FMD and the change in number of CD $34+$ cells $(R=$ $0.217, P=0.499$ ), or between the change in IGF-I and the change in FMD $(R=0.080, P=0.785)$ and the change in CD $34+$ cells $(R=0.425, P=0.169)$. Smoking habits and gender were not related to either change in FMD or change in number of CD34+ cells. Age was correlated with change in CD34 + cells after 1 month $\left(r^{2}=0.367, P=0.04\right.$; Fig. 3$)$. 
Table 2 Vascular endothelial function, PWV, and PWA during 1 year of recombinant human growth hormone (rhGH) replacement in adult patients with GH deficiency.

\begin{tabular}{|c|c|c|c|c|c|}
\hline & Baseline & $\begin{array}{l}\text { 6-month rhGH } \\
\text { replacement }\end{array}$ & $\begin{array}{l}\text { 1-year rhGH } \\
\text { replacement }\end{array}$ & $\begin{array}{l}\text { Overall } \\
P \text { value }\end{array}$ & $\begin{array}{l}\text { Control } \\
\text { values }\end{array}$ \\
\hline IGF-I (nmol/I) & $10.4 \pm 4.5$ & $18.4 \pm 10.1$ & $20.5 \pm 8.0$ & 0.001 & \\
\hline IGFBP-3 (mg/l) & $2.7 \pm 1.2$ & $4.0 \pm 1.7$ & $4.0 \pm 1.1$ & 0.003 & \\
\hline Glucose $(\mathrm{mmol} / \mathrm{l})$ & $5.1 \pm 0.6$ & $5.1 \pm 0.7$ & $4.9 \pm 0.7$ & 0.062 & \\
\hline Total cholesterol $(\mathrm{mmol} / \mathrm{l})$ & $5.5 \pm 0.1$ & $5.2 \pm 1.1$ & $5.2 \pm 0.8$ & 0.335 & \\
\hline LDL cholesterol $(\mathrm{mmol} / \mathrm{l})$ & $3.7 \pm 0.8$ & $3.6 \pm 0.4$ & $3.5 \pm 0.8$ & 0.545 & \\
\hline $\mathrm{HDL}$ cholesterol $(\mathrm{mmol} / \mathrm{l})$ & $1.4 \pm 0.4$ & $1.3 \pm 0.4$ & $1.4 \pm 0.4$ & 0.122 & \\
\hline Triglycerides $(\mathrm{mmol} / \mathrm{l})$ & $1.6 \pm 0.7$ & $1.3 \pm 0.6$ & $1.6 \pm 0.7$ & 0.064 & \\
\hline FMD $(\%)$ & $3.5+1.8$ & $6.0+2.5$ & $5.1+2.5$ & 0.008 & $9.1+4.7$ \\
\hline NTG (\%) & $13.5 \pm 5.2$ & $14.9 \pm 6.5$ & $13.1 \pm 4.8$ & 0.427 & $18.0 \pm 5.9$ \\
\hline Aortic PWV $(\mathrm{cm} / \mathrm{s})$ & $7.9 \pm 1.9$ & $7.7 \pm 1.9$ & $7.7 \pm 2.2$ & 0.777 & $8.1 \pm 1.3$ \\
\hline Brachial systolic pressure $(\mathrm{mmHg})$ & $136.2 \pm 11.9$ & $131.6 \pm 17.2$ & $136.6 \pm 15.0$ & 0.302 & $133.0 \pm 7.0$ \\
\hline Brachial diastolic pressure $(\mathrm{mmHg})$ & $84.1 \pm 8.1$ & $80.7 \pm 8.1$ & $81.2 \pm 8.1$ & 0.056 & $83.8 \pm 5.6$ \\
\hline Brachial pulse pressure $(\mathrm{mmHg})$ & $52.1+11.3$ & $50.9+17.6$ & $55.4+10.2$ & 0.374 & $49.2+6.9$ \\
\hline Central systolic pressure $(\mathrm{mmHg})$ & $135.6 \pm 13.5$ & $135.1 \pm 22.6$ & $138.1 \pm 17.5$ & 0.812 & $129.8 \pm 7.5$ \\
\hline Central pulse pressure $(\mathrm{mmHg})$ & $51.8 \pm 12.1$ & $54.8 \pm 22.3$ & $57.0 \pm 13.7$ & 0.569 & $46.8 \pm 8.1$ \\
\hline Augmentation index & $26.6 \pm 10.6$ & $24.9 \pm 11.6$ & $25.7 \pm 11.4$ & 0.483 & $32.9 \pm 11.9$ \\
\hline
\end{tabular}

Data were compared with ANOVA with repeated measurements. Reference values of age- and gender-matched healthy controls. FMD, flow-mediated vasodilatation; NTG, nitroglycerin; PWV, pulse wave velocity.

\section{Discussion}

The novel finding in this study is the beneficial effect of treatment with rhGH both on the number of circulating CD34+ cells and on endothelial function, which was manifest within 6 months after the start of treatment and maintained 6 months thereafter.

Hypopituitarism in general is associated with increased mortality, predominantly due to cardiovascular diseases (23), which has been ascribed to untreated GHD (24). These observations in patients with GHD are related to an increased prevalence of cardiovascular risk factors, such as hypertension, dyslipidemia, and alterations in body composition (2). Indeed, intima-media thickness (IMT) is increased in patients with GHD compared with control subjects (25). However, the effect of rhGH replacement on cardiovascular health is still subject to debate. IMT decreased during rhGH replacement in one study (25), whereas others reported that intima-media thickness was not different compared with controls $(3,26)$ and remained unchanged during rhGH replacement (6).

In our study, the number of circulating CD34 + cells in adults with GHD increased within 6 months of rhGH replacement and remained stable thereafter. These results are in line with the very recently observed potential of rhGH treatment to increase the number of circulating endothelial progenitor cells (classified as CD133/VEGFR2 cells and colony-forming units) in healthy volunteers (27). In addition, the potential of rhGH to positively influence hematopoiesis has previously been shown in another clinical setting, that is, harvesting of CD34+ cells destined for autologous hematopoietic stem cell transplantation in patients with relapsed or refractory hematologic malignancies (28).
Endothelial function was measured in our study before and during rhGH replacement by assessing flowmediated vasodilatation (FMD). Indeed, at baseline FMD was decreased compared with reference values obtained in our vascular unit. The observed improved FMD after rhGH replacement was also observed within 6 months and continued until the end of the study. These data are in agreement with earlier other reports assessing the effects of rhGH replacement on endothelial function $(6,25,29)$. A putative mechanism by which rhGH replacement improves vascular function is IGF-Imediated stimulation of nitric oxide synthesis in endothelial cells $(30,31)$.

Since we intended to use circulating bone marrowderived cells as biomarkers for cardiovascular health, we focused on CD34 + cells only, which are closely linked to cardiovascular risk, even more closely than CD34+ / VEGFR + cells (17). The potential mechanisms, responsible for the increase in the number of CD34+ cells in our study, are not clear. Improvement in endothelial function is associated with increased nitric oxide bioavailability, in particular in the bone marrow (32), which is associated with increased mobilization of CD $34+$ cells. Indeed, GH treatment was found to induce markers of nitric oxide bioavailability in healthy volunteers (27). In addition, CD $34+$ cells express both GH and IGF-I receptors (33) as is the case for several other cell types that could be involved. Indeed, studies in rodents and on fetal bone marrow demonstrate direct effects of GH and IGF-I on hematopoiesis $(33,34)$. It is likely that complex interactions between circulating IGF-I, IGFBP-3, and their effects on nitric-oxide bioavailability result in the increase in CD34+ cells in our study. Indeed, a recent study reported that IGFBP-3 also promotes migration, tube formation of $\mathrm{CD} 34+$ cells, 

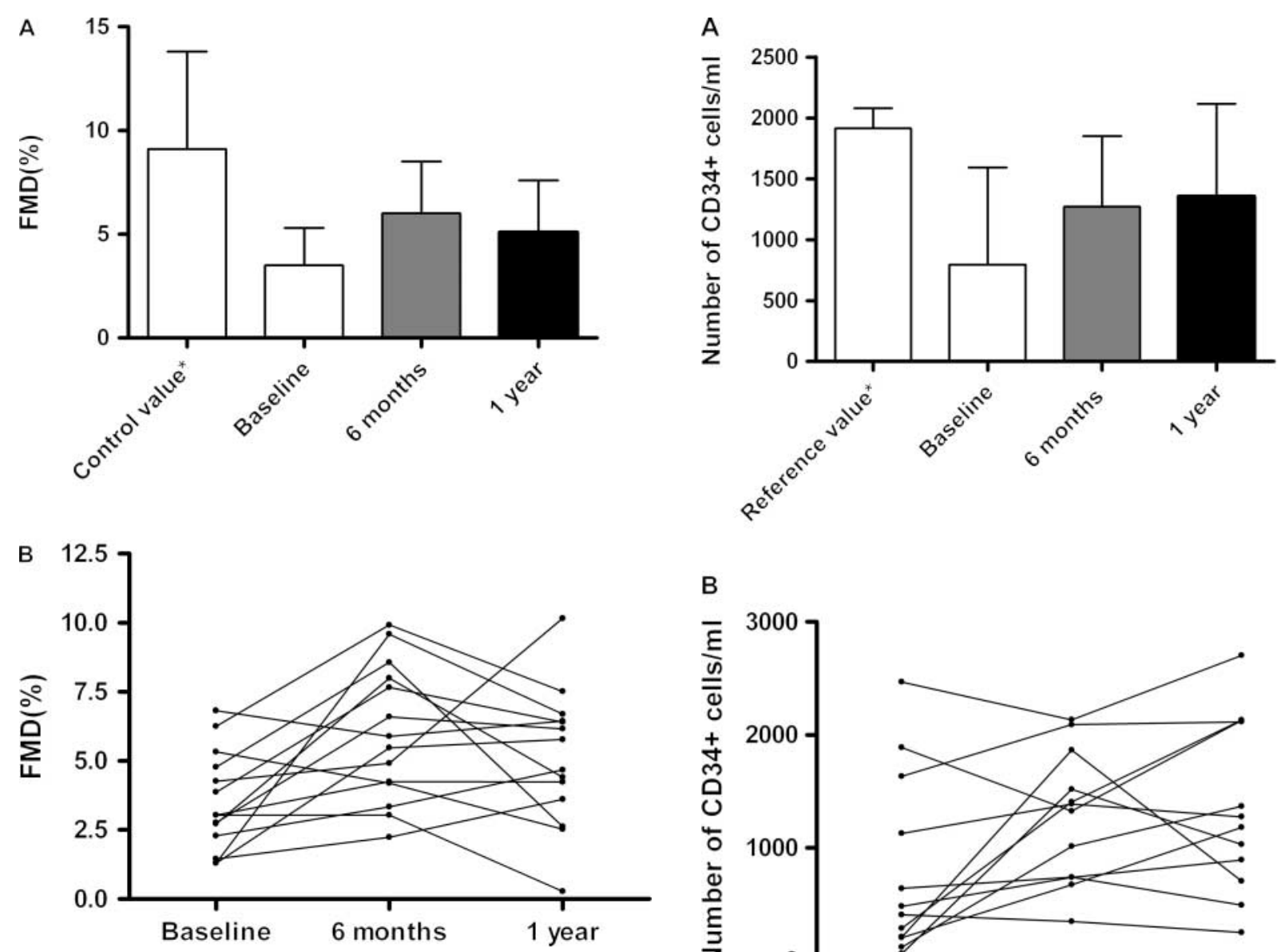

Figure 1 Percentage flow-mediated dilatation (FMD) during 1 year of rhGH replacement in adult patients with $\mathrm{GH}$ deficiency increases significantly, predominantly in the first 6 months of rhGH replacement (overall $P=0.008$ ). (A) The first white bar represents the control value* of FMD in age- and gender-matched healthy subjects obtained in our center. The second white bar represents baseline, grey bar 6 months of rhGH replacement, and black bar 1 year of rhGH replacement. (B) Individual FMD during 1 year of rhGH replacement.

and differentiation of these cells into endothelial cells, leading to increased vessel stabilization and quicker blood vessel development (35) illustrating the complexity of potential mechanisms involved in rhGH effects.

In addition, we also determined several measures of arterial stiffness before and during 1 year of rhGH replacement. Pulse wave velocity, as a direct measure of arterial stiffness, did not change during the study. This is in contrast with an earlier report by McCallum et al. (36). In that study, PWV decreased from 8.1 to $6.7 \mathrm{~m} / \mathrm{s}$ during 6 months of rhGH replacement in 16 patients with GHD (36). In our study, no change in PWV was found after 6 months or 1 year of rhGH replacement. The discrepancies between the two studies might be related to a more disadvantageous cardiovascular risk profile in our patients group, since they were older (average 7 years), included more men (64\% vs $37 \%)$ and had a higher BMI $\left(29.4 \mathrm{vs} 27.8 \mathrm{~kg} / \mathrm{m}^{2}\right)$. The small improvement in central systolic blood pressure and augmentation index in a

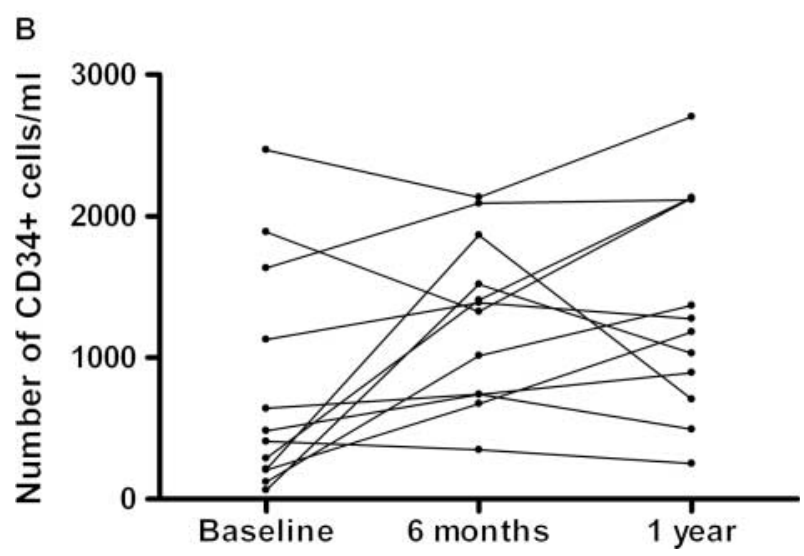

Figure 2 Number of circulating CD34+ hematopoietic stem cells during 1 year of rhGH replacement in adult patients with $\mathrm{GH}$ deficiency increases (overall $P=0.010$ ). (A) The first white bar represents the reference value* of the number of circulating CD34+ cells in nine men with a mean age of $61 \pm 5$ years and a BMI of $24.2 \pm 1.0 \mathrm{~kg} / \mathrm{m}^{2}$ obtained in our center. Second white bar represents baseline, grey bar 6 months of rhGH replacement, and black bar 1 year of rhGH replacement. (B) Individual concentrations of circulating CD34+ hematopoietic stem cells during 1 year of rhGH replacement.

previous report (9) was not observed in our study, possibly due to the differences in patient groups or the limited number of patients studied.

Although we did not find a statistically significant decrease in lipid concentrations in our limited number of patients, LDL cholesterol decreased by $0.2 \mathrm{mmol} / \mathrm{l}$ and total cholesterol by $0.3 \mathrm{mmol} / \mathrm{l}$. In a meta-analysis of short-term trials (treatment up to 18 months) with rhGH replacement in GHD (7), the weighted mean differences for LDL and total cholesterol were -0.53 and $-0.34 \mathrm{mmol} / \mathrm{l}$ respectively. Thus, the changes in lipid concentrations in our study move in a similar direction to the changes noted in rhGH replacement in general.

The major study limitation is the low number of patients that were included due to the fact that GHD is a rare disease and that our study design excluded subjects 


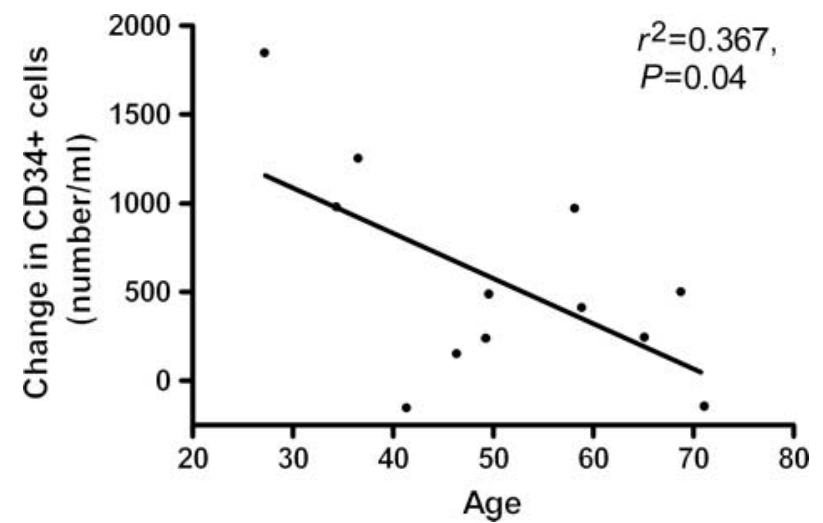

Figure 3 Correlation between change number of circulating CD34+ hematopoietic stem cells during 1 year of rhGH replacement in adult patients with GH deficiency and age.

with a history of cardiovascular disease, which could influence our measurements. In addition, the beneficial effects of rhGH replacement have been widely accepted, which limits the possibilities to study the natural course of this disease with respect to CD $34+$ cells. Nonetheless, the differences in CD34+ cell numbers found in this group with a wide age range are relatively major, which supports a role of GH in the regulation of this cell type. Thus, this study provides new data into the relationship of circulating endothelial progenitor cells and GH, which can be used as a basis for additional larger studies. Interestingly, the change in CD34+ cells showed an inverse relationship with advancing age, indicating that the effect of rhGH on CD34+ cells is age dependent.

In conclusion, one year of rhGH replacement in adult patients with GHD improved endothelial function and increased the number of CD34+ cells. Since these outcome parameters are strong biomarkers for cardiovascular disease risk, our data indicate that $\mathrm{GH}$ replacement in adults with GHD may have beneficial effects on the vasculature.

\section{Acknowledgements}

We thank Jos op 't Roodt for skilled performance of vascular function tests and Jacques Duijs for expert technical assistance. Agatha van der Klaauw was supported by an AGIKO grant of the Netherlands Organization for Health Research and Development (grant number 92003423). Eelco de Koning is recipient of a Career Development Award by the Dutch Diabetes Foundation. Hetty de Boer was supported by a grant from the Netherlands Heart Foundation (grant number 2005B106).

\section{References}

1 de Boer H, Blok GJ \& Van der Veen EA. Clinical aspects of growth hormone deficiency in adults. Endocrine Reviews 199516 63-86.
2 van der Klaauw AA, Biermasz NR, Feskens EJ, Bos MB, Smit JW, Roelfsema F, Corssmit EP, Pijl H, Romijn JA \& Pereira AM. The prevalence of the metabolic syndrome is increased in patients with GH deficiency, irrespective of long-term substitution with recombinant human GH. European Journal of Endocrinology 2007 $156455-462$.

3 Elhadd TA, Abdu TA, Oxtoby J, Kennedy G, McLaren M, Neary R, Belch JJ \& Clayton RN. Biochemical and biophysical markers of endothelial dysfunction in adults with hypopituitarism and severe GH deficiency. Journal of Clinical Endocrinology and Metabolism $2001864223-4232$.

4 Evans LM, Davies JS, Goodfellow J, Rees JA \& Scanlon MF. Endothelial dysfunction in hypopituitary adults with growth hormone deficiency. Clinical Endocrinology 199950 457-464.

5 Lanes R, Gunczler P, Lopez E, Esaa S, Villaroel O \& Revel-Chion R. Cardiac mass and function, carotid artery intima-media thickness, and lipoprotein levels in growth hormone-deficient adolescents. Journal of Clinical Endocrinology and Metabolism 200186 10611065.

6 Abdu TA, Elhadd TA, Buch H, Barton D, Neary R \& Clayton RN. Recombinant GH replacement in hypopituitary adults improves endothelial cell function and reduces calculated absolute and relative coronary risk. Clinical Endocrinology 200461 387-393.

7 Maison P, Griffin S, Nicoue-Beglah M, Haddad N, Balkau B \& Chanson P. Impact of growth hormone $(\mathrm{GH})$ treatment on cardiovascular risk factors in GH-deficient adults: a metaanalysis of blinded, randomized, placebo-controlled trials. Journal of Clinical Endocrinology and Metabolism 200489 2192-2199.

8 Pfeifer M, Verhovec R, Zizek B, Prezelj J, Poredos P \& Clayton RN. Growth hormone (GH) treatment reverses early atherosclerotic changes in GH-deficient adults. Journal of Clinical Endocrinology and Metabolism 199984 453-457.

9 Smith JC, Evans LM, Wilkinson I, Goodfellow J, Cockcroft JR, Scanlon MF \& Davies JS. Effects of GH replacement on endothelial function and large-artery stiffness in GH-deficient adults: a randomized, double-blind, placebo-controlled study. Clinical Endocrinology 200256 493-501.

10 van der Klaauw AA, Romijn JA, Biermasz NR, Smit JW, van Doorn J, Dekkers OM, Roelfsema F \& Pereira AM. Sustained effects of recombinant GH replacement after 7 years of treatment in adults with GH deficiency. European Journal of Endocrinology 2006 155 701-708.

11 Rabelink TJ, de Boer HC, de Koning EJ \& van Zonneveld AJ. Endothelial progenitor cells: more than an inflammatory response? Arteriosclerosis, Thrombosis, and Vascular Biology 2004 24 834-838.

12 Loomans CJ, de Koning EJ, Staal FJ, Rookmaaker MB, Verseyden C, de Boer HC, Verhaar MC, Braam B, Rabelink TJ \& van Zonneveld AJ. Endothelial progenitor cell dysfunction: a novel concept in the pathogenesis of vascular complications of type 1 diabetes. Diabetes 200453 195-199.

13 Hill JM, Zalos G, Halcox JP, Schenke WH, Waclawiw MA, Quyyumi AA \& Finkel T. Circulating endothelial progenitor cells, vascular function, and cardiovascular risk. New England Journal of Medicine $2003 \mathbf{3 4 8} 593-600$.

14 Werner N, Kosiol S, Schiegl T, Ahlers P, Walenta K, Link A, Bohm M \& Nickenig G. Circulating endothelial progenitor cells and cardiovascular outcomes. New England Journal of Medicine 2005 353 999-1007.

15 Yoder MC, Mead LE, Prater D, Krier TR, Mroueh KN, Li F, Krasich R, Temm CJ, Prchal JT \& Ingram DA. Redefining endothelial progenitor cells via clonal analysis and hematopoietic stem/progenitor cell principals. Blood 2007109 1801-1809.

16 Urbich C \& Dimmeler S. Endothelial progenitor cells: characterization and role in vascular biology. Circulation Research 200495 343-353.

17 Fadini GP, de Kreutzenberg SV, Coracina A, Baesso I, Agostini C, Tiengo A \& Avogaro A. Circulating CD $34+$ cells, metabolic syndrome, and cardiovascular risk. European Heart Journal 2006 $272247-2255$. 
18 van Wijk JP, de Koning EJ, Cabezas MC, op't RJ, Joven J, Rabelink T] \& Hoepelman AI. Comparison of rosiglitazone and metformin for treating HIV lipodystrophy: a randomized trial. Annals of Internal Medicine 2005143 337-346.

19 van Wijk JP, de Koning EJ, Cabezas MC, Joven J, op’t RJ, Rabelink T] \& Hoepelman AM. Functional and structural markers of atherosclerosis in human immunodeficiency virus-infected patients. Journal of the American College of Cardiology $2006 \mathbf{4 7}$ 1117-1123.

20 Wilkinson IB, Fuchs SA, Jansen IM, Spratt JC, Murray GD, Cockcroft JR \& Webb DJ. Reproducibility of pulse wave velocity and augmentation index measured by pulse wave analysis. Journal of Hypertension 199816 2079-2084.

21 Kelly R \& Fitchett D. Noninvasive determination of aortic input impedance and external left ventricular power output: a validation and repeatability study of a new technique. Journal of the American College of Cardiology 199220 952-963.

22 Verbeke F, Segers P, Heireman S, Vanholder R, Verdonck P \& Van Bortel LM. Noninvasive assessment of local pulse pressure: importance of brachial-to-radial pressure amplification. Hypertension $200546244-248$.

23 Tomlinson JW, Holden N, Hills RK, Wheatley K, Clayton RN, Bates AS, Sheppard MC \& Stewart PM. Association between premature mortality and hypopituitarism. West Midlands Prospective Hypopituitary Study Group. Lancet 2001357 425-431.

24 Rosen T \& Bengtsson BA. Premature mortality due to cardiovascular disease in hypopituitarism. Lancet 1990336 285-288.

25 Pfeifer M, Verhovec R \& Zizek B. Growth hormone (GH) and atherosclerosis: changes in morphology and function of major arteries during GH treatment. Growth Hormone and IGF Research 19999 (Suppl A) 25-30.

26 Lanes R, Soros A, Flores K, Gunczler P, Carrillo E \& Bandel J. Endothelial function, carotid artery intima-media thickness, epicardial adipose tissue, and left ventricular mass and function in growth hormone-deficient adolescents: apparent effects of growth hormone treatment on these parameters. Journal of Clinical Endocrinology and Metabolism 200590 3978-3982.

27 Thum T, Fleissner F, Klink I, Tsikas D, Jakob M, Bauersachs J \& Stichtenoth DO. Growth hormone treatment improves markers of systemic nitric oxide bioavailability via insulin-like growth factor-1. Journal of Clinical Endocrinology and Metabolism 200792 4172-4179.

28 Carlo-Stella C, Di Nicola M, Milani R, Guidetti A, Magni M, Milanesi M, Longoni P, Matteucci P, Formelli F, Ravagnani F,
Corradini P \& Gianni AM. Use of recombinant human growth hormone (rhGH) plus recombinant human granulocyte colonystimulating factor (rhG-CSF) for the mobilization and collection of CD34 + cells in poor mobilizers. Blood 2004103 3287-3295.

29 Evans LM, Davies JS, Anderson RA, Ellis GR, Jackson SK, Lewis MJ, Frenneaux MP, Rees A \& Scanlon MF. The effect of GH replacement therapy on endothelial function and oxidative stress in adult growth hormone deficiency. European Journal of Endocrinology $2000142254-262$.

30 Tsukahara H, Gordienko DV, Tonshoff B, Gelato MC \& Goligorsky MS. Direct demonstration of insulin-like growth factor-I-induced nitric oxide production by endothelial cells. Kidney International $1994 \mathbf{4 5} 598-604$.

31 Boger RH, Skamira C, Bode-Boger SM, Brabant G, von zur MA \& Frolich JC. Nitric oxide may mediate the hemodynamic effects of recombinant growth hormone in patients with acquired growth hormone deficiency. A double-blind, placebo-controlled study. Journal of Clinical Investigation 199698 2706-2713.

32 Aicher A, Heeschen C, Mildner-Rihm C, Urbich C, Ihling C, Technau-Ihling K, Zeiher AM \& Dimmeler S. Essential role of endothelial nitric oxide synthase for mobilization of stem and progenitor cells. Nature Medicine 20039 1370-1376.

33 Hanley MB, Napolitano LA \& McCune JM. Growth hormoneinduced stimulation of multilineage human hematopoiesis. Stem Cells 200523 1170-1179.

34 Merchav S. The haematopoietic effects of growth hormone and insulin-like growth factor-I. Journal of Pediatric Endocrinology and Metabolism $199811677-685$.

35 Chang KH, Chan-Ling T, McFarland EL, Afzal A, Pan H, Baxter LC, Shaw LC, Caballero S, Sengupta N, Li CS, Sullivan SM \& Grant MB. IGF binding protein-3 regulates hematopoietic stem cell and endothelial precursor cell function during vascular development. PNAS $2007 \mathbf{1 0 4} 10595-10600$.

36 McCallum RW, Sainsbury CA, Spiers A, Dominiczak AF, Petrie JR, Sattar N \& Connell JM. Growth hormone replacement reduces C-reactive protein and large-artery stiffness but does not alter endothelial function in patients with adult growth hormone deficiency. Clinical Endocrinology $200562473-479$.

Received 21 April 2008

Accepted 28 April 2008 